研究課題別評価

1 研究課題名: シナプス回路形成機構のゲノム遺伝学的解析と精神研究への応用

2 研究者氏名:曽根 雅紀

3. 研究のねらい:

ヒト、マウス、ショウジョウバエなどの多くの生物の全ゲノム配列が決定された現在でも、未だに 機能が未解析の遺伝子が多く存在する。ゲノム上の遺伝子の大多数は神経系で発現しているが、 そのうちで神経系における機能が記載されているものは少数であり、未同定の重要な機能分子を 探索していくことが、脳神経系の機能原理の解明、および脳神経系の機能異常によって起きる 様々な精神神経疾患の発症機序と病態解明のために不可欠である。未同定の機能分子を網羅 的に探索していくためには様々なアプロ一チがあるが、その中でもショウジョウバエ遺伝学はある 生物学的プロセスにおいて重要な機能を持つ未知の遺伝子を探索するための強力な手法であり、 実際に例えば発生生物学の分野では、多くの先駆的な研究成果がショウジョウバエ遺伝学から 明らかになってきている。本研究では、ショウジョウバエ遺伝学を用いて脳神経系の機能および病 態に関わる新規分子の同定を目指した。特に、われわれがこれまでに明らかにしてきたシナプス 分子のシナプスへの局在化機構に関する知見を応用して、シナプスに局在化する分子を遺伝学 的に探索するための新しい方法の開発を目指した。

\title{
4. 研究成果:
}

われわれは、ショウジョウバエの既知シナプス分子であるHIG 蛋白質のシナプスへの局在化機 構を解析し、シナプスへの局在化シグナルを同定するとともに、その局在がアルツハイマ一病原 因遺伝子である APP (アミロイド前駆体蛋白質)のショウジョウバエホモログによって制御されてい ることを明らかにした。さらに、シナプスへの局在化能を失った改変 HIG 蛋白質を用いてシナプス 分子のエクソントラップスクリーニングを行っていくための予備実験を現在進めている。

以上の研究の過程で、われわれは、神経変性疾患、特にアルツハイマー病に関連する可能性 のある興味深い新規ショウジョウバエ遺伝子(仮称:517 遺伝子)を同定した。517 遺伝子のホモ 接合体は羽化後早期に死亡した。さらに、この早期死亡の表現型は、APP 遺伝子との二重 loss-of-function 変異で顕著に増悪した。517 変異体は、複眼神経組織において、光受容神経細 胞の発生異常と組織極性異常を示し、いくつかの個体においては神経変性が起きていることが示 唆された。517 変異体の翅には、Notch シグナルの異常を示唆する表現型が認められ、遺伝学的 レポーター系統を用いた実験から、APP と Notch を切断するプロテアーゼであるガンマセクレター ゼ活性が低下している可能性が示唆された。また、ショウジョウバエ APP 蛋白質は神経細胞内で シナプスに輸送されて局在するが、517 変異体では APP のシナプスへの輸送が異常になり、細 胞体の核辺縁領域(小胞体である可能性がある)に留まっているのが観察された。以上の結果か ら、517 遺伝子産物は、APP および関連分子の小胞体からのトラフィッキングを制御しており、 517 変異体においては、それらの分子の局在および機能が異常になることによって神経変性が起 きるのではないかと考え、この仮説を検証するための実験を現在進めているところである。

これまでに、家族性アルツハイマ一病の原因遺伝子として APP およびガンマセクレターゼの構 成要素であるプレセニリンが同定され、APP のプロセシング産物であるアミロイドベータの異常産 生と沈着がアルツハイマ一病発症の原因であるとする有力な仮説がある。しかしながら、ヒト変異 型APPを発現するマウスにおいて、アミロイドベータの沈着、シナプスの機能異常、および認知障 害が観察されるものの、神経変性がほとんど起きないことから、アルツハイマ一病神経変性には 未知の分子機構がさらに寄与している可能性がある。 517 遺伝子産物が APP および関連分子の 細胞内トラフイツキングを制御している新規分子であれば、この分子の発見が、未だによくわかっ ていない APP の生理的な機能の解明に示唆を与える可能性がある。さらに、興味深いのは、 517 変異体で神経変性が起き、この表現型が $A P P$ 機能喪失変異によって増悪するということである。 したがって、今後の課題としては、517 変異体においていかなる分子機序で神経変性が起きるの 
かを明らかにしていくことが重要である。それによって、APP の細胞生物学的な挙動および機能と 神経変性を結びつける分子経路を明らかにすることができれば、アルツハイマー病神経変性機構 の解明に示唆を与え貢献していくことができるものと期待される。

\section{5 自己評価:}

ショウジョウバエ遺伝学の最大のメリットは未知の重要な分子を何も手がかりのないところから 探索し発見できるということであり、脳神経系の機能と病態に関わる全く新しい分子を発見してい きたいと考えたことが本研究の動機である。本研究では、エクソントラップ法を応用したシナプス分 子スクリーニング法の開発を試みたが、現在、既知シナプス分子を用いた予備実験の段階にある。 最近、ゲノム研究の成果を応用した新規シナプス分子の同定が報告されてきているので、それら を用いて予備実験を行っていこうとしている。本研究において、APP のシナプス局在化機構を解 析していた過程で、おそらく APP および関連分子のトラフィッキングに関わると思われる全く新し い分子を発見した。興味深いことに、発見した新規分子の表現型では神経変性が起き、またこの 分子には哺乳類にもよく保存されたホモログがあることから、この分子を解析していくことによって、 アルツハイマ一病の神経変性機構解明に手がかりを与えられるのではないかと期待している。ぜ ひ早期に、(1) 新規分子の分子機能 (APP および関連分子のトラフイッキング制御 ?)、(2) 新規 分子の変異体における神経変性·早期死亡の原因、の二点を解明し、論文としてまとめたいと思 っている。この二点をクリアに明らかにすることができれば、APP の生理的な機能およびそれを介 した神経細胞の生存維持機構に重要な示唆を与えることができるのではないかと期待している。

6 研究総括の見解:

シナップスに局在する分子の探索の過程で、アルツハイマー病の原因蛋白質をもたらす APP のシナプスへの輸送に関与すると考えられる蛋白質をコードする517遺伝子を同定したことは評 価できる。しかし、その機能、特にアルツハイマ一病の理解との関連における機能の解明が端緒 についたばかりでさきがけ研究が終了してしまうのは残念である。もう少し鋭い切りロでの今後の 発展を期待する。

7 主な論文等:

論文

1. M. Yoshizawa, M. Sone, N. Matsuo, T. Nagase, O. Ohara, Y. Nabeshima and M. Hoshino: Dynamic and coordinated expression profile of Dbl-family guanine nucleotide exchange factors in the developing mouse brain. Gene Expr. Pat. 3: 375-381, 2003

2. M. Yoshizawa, M. Sone ${ }^{*}$, T. Kawauchi*, Y. V. Nishimura, M. Terao, K. Chihama, Y. Nabeshima and M. Hoshino: Involvement of a Rac activator, P-Rex1, in neurotrophin-derived signaling and neuronal migration. J. Neurosci. 25: 4406-4409, 2005 (* : equal contribution)

3. M. Hoshino, S. Nakamura, K. Mori, T. Kawauchi, M. Terao, Y. V. Nishimura, A. Fukuda, T. Fuse, N. Matsuo, M. Sone, M. Watanabe, H. Bito, T. Terashima, C. V. E. Wright, Y. Kawaguchi, K. Nakao and Y. Nabeshima: Ptf1a, a bHLH transcriptional gene, defines GABAergic neuronal fates in cerebellum. Neuron 47: 201-213, 2005 